\title{
THE EVALUATION OF AVAILABILITY OF THE SERVICEABILITY ASSURANCE SUBSYSTEM POSTS \\ OCENA GOTOWOŚCI STANOWISK PODSYSTEMU ZAPEWNIANIA ZDATNOŚCI
}

\author{
Klaudiusz Migawa \\ University of Technology and Life Sciences \\ e-mail:km@karor.com.pl
}

\begin{abstract}
In complex transport means systems, in order to assure the possibility of appropriate carrying out of transport tasks it is necessary to maintain task serviceability status. It is achieved as a result of carrying out of service and repair processes at serviceability assurance subsystem posts. The possibility of appropriate carrying out of service and repair tasks assigned to the availability assurance subsystem depends to a large extent on the availability of the posts of the subsystem. This article presents the results of tests on the evaluation of availability of the serviceability assurance subsystem posts in transport means utilization system. An actual city bus transport system was used as test example. The presented results of the evaluation of the serviceability assurance subsystem posts were reached with the assumption that random variables describing the periods of time the posts remain available or unavailable have exponential and Erlang distributions. Source data necessary to determine the availability of the serviceability assurance subsystem posts were obtained at a selected actual city bus transport system basing on utilization data and the method of passive experiment in natural utilization conditions.
\end{abstract}

Keywords: transport system, serviceability assurance subsystem, availability

Streszczenie: $W$ zlożonych systemach eksploatacji środków transportu, $w$ celu zapewnienia możliwości prawidłowej realizacji zadań przewozowych, konieczne jest utrzymywanie środków transportu w stanie zdatności zadaniowej. Uzyskiwane jest to $w$ wyniku realizacji procesów obstugowo-naprawczych na stanowiskach podsystemu zapewniania zdatności. Możliwość prawidtowej realizacji zadań obstugowonaprawczych przydzielonych podsystemowi zapewniania zdatności, zależy $w$ istotny sposób od gotowości stanowisk tego podsystemu. W artykule przedstawiono wyniki badań dotyczace oceny gotowości stanowisk podsystemu zapewniania zdatności w systemie eksploatacji środków transportu. Jako przykład obiektu badań zostat wybrany rzeczywisty system eksploatacji autobusów komunikacji miejskiej. Prezentowane wyniki oceny gotowości stanowisk podsystemu zapewniania zdatności zostały wyznaczone przy przyjęciu założenia, że zmienne losowe opisujace czasy przebywania stanowisk $w$ stanach gotowości $i$ niegotowości maja rozkłady wyktadnicze $i$ Erlanga. Dane źródtowe niezbędne do wyznaczenia gotowości stanowisk podsystemu zapewniania zdatności, uzyskano na podstawie badań eksploatacyjnych przeprowadzonych $w$ wybranym rzeczywistym systemie eksploatacji środków transportu, metoda eksperymentu biernego w naturalnych warunkach eksploatacji.

Slowa kluczowe: system transportowy, podsystem zapewniania zdatności, gotowość 
The evaluation of availability of the serviceability assurance subsystem posts Ocena gotowości stanowisk podsystemu zapewniania zdatności

\section{Introduction}

The issues presented in this article are connected with the problems linked to the evaluation of the availability of serviceability assurance subsystem posts in a complex technological objects (e.g. transport means) utilization system. The primary goal for the operation of the transport means utilization systems is the correct and efficient carrying out of the assigned transport tasks. The correct and efficient carrying out of transport tasks is possible only when the required number of technological objects (transport means) are serviceable work-wise. This is obtained through the carrying out of service and repair processes at serviceability assurance subsystem posts. Problems connected with the efficiency of the functioning of complex technological systems as well as the questions of controlling of the processes carried out at serviceability assurance subsystem posts constitute the basis of the considerations of numerous research papers, e.g. $[4,7,9$, $11,12,13,17]$.

This article presents the method of determining and evaluating of the availability of serviceability assurance subsystem posts. The goal of the serviceability assurance subsystem posts is the servicing of a specific number of technological objects (transport means) over a time interval designated for the task. The goal thus defined is carried out at individual serviceability assurance subsystem posts by specialist teams equipped with appropriate devices and tools. The presented method makes it possible to determine and evaluate the availability of serviceability assurance subsystem posts at point $t$ as well as over time interval $\tau$. The characteristics of the evaluation of serviceability assurance subsystem posts were presented in general terms. Then, for utilization data obtained during tests carried out in actual transport means utilization system, the availability of individual serviceability assurance subsystem posts was determined, assuming that the time of availability and the time of renovation of individual posts are described with exponential and Erlang distributions.

The resulting characteristics may be used to evaluate the availability of the individual posts, units of post of specific structures as well the serviceability assurance subsystem as a whole. The obtained evaluation of the availability of serviceability subsystem posts constitutes a piece of information the use of which in the process of control of complex technological system will facilitate the choice of rational control decisions connected with adjusting the serviceability assurance subsystem to the currents needs of the system. In particular, it can be connected with:

- post modernization,

- replacing the posts of higher reliability, availability and operational susceptibility,

- determining the number of posts of different types,

- determining the structures through which the individual posts and post units are conjugated, 
- introducing universal posts at which, if necessity arises, both the service processes as well as technological object repair may be carried out,

- changes in the organization and conditions of carrying out processes at the analyzed subsystem posts.

\section{Availability of serviceability assurance subsystem posts}

If:

$$
V_{i j}(t)=P\left(X_{i j}<t\right), i=1,2, \ldots, p, j=1,2, \ldots, q_{i},
$$

is the distribution function of serviceability time $X_{i j}, i=1,2, \ldots, p, j=1,2, \ldots, q_{i}$ of a single post $s_{i j}, i=1,2, \ldots, p, j=1,2, \ldots, q_{i}$ at serviceability assurance subsystem, while:

$$
W_{i j}(t)=P\left(Y_{i j}<t\right), i=1,2, \ldots, p, j=1,2, \ldots, q_{i},
$$

is the distribution function of renovation time $Y_{i j}, i=1,2, \ldots, p, j=1,2, \ldots, q_{i}$ of a single post $s_{i j}, i=1,2, \ldots, p, j=1,2, \ldots, q_{i}$ at serviceability assurance subsystem, then the availability $G_{i j}(t)$ of a single post $s_{i j}$ in serviceability assurance subsystem, determined at point $t$ as probability that at point $t$ the post $s_{i j}$ is serviced and provided for, is defined by the formula:

$$
G_{i j}(t)=R_{i j}(t)+\int_{0}^{t} R_{i j}(t-x) d H_{i j}(x)
$$

as well as availability $G_{O_{i j}}(t, \tau)$ of a single post $s_{i j}$ of serviceability subsystem, determined over time interval $<t, t+\tau)$ as probability that over time interval $<t, t+\tau$ ) the post $s_{i j}$ is available and provided for, is defined by the formula:

$$
G_{O_{i j}}(t, \tau)=R_{i j}(t+\tau)+\int_{0}^{t} R_{i j}(t+\tau-x) d H_{i j}(x)
$$

where:

$$
\begin{aligned}
R_{i j}(t)- & \text { is the function of reliability of a single post } s_{i j} \text { of the } \\
& \text { serviceability assurance subsystem, } \\
H_{i j}(t)- & \text { is the function of renovation of a single post } s_{i j} \text { of serviceability } \\
& \text { assurance. }
\end{aligned}
$$

In the case, in which $t \rightarrow \infty$, the functions defined by formulas (3) and (4) have limit values called limit availability coefficients:

$$
G_{i j}=\lim _{t \rightarrow \infty} G_{i j}(t)=\frac{E\left(X_{i j}\right)}{E\left(X_{i j}\right)+E\left(Y_{i j}\right)}
$$


The evaluation of availability of the serviceability assurance subsystem posts Ocena gotowości stanowisk podsystemu zapewniania zdatności

as well as

$$
G_{O_{i j}}(\tau)=\lim _{t \rightarrow \infty} G_{O_{i j}}(t, \tau)=\frac{1}{E\left(X_{i j}\right)+E\left(Y_{i j}\right)} \cdot \int_{\tau}^{\infty} R_{i j}(x) d x,
$$

where:

$E\left(X_{i j}\right)-$ is the expected value of the time of serviceability of a single post $s_{i j}$ of the serviceability assurance subsystem,

$E\left(Y_{i j}\right)-$ is the expected value of the time of renovation of a single post $s_{i j}$ of the serviceability assurance subsystem.

In order to determine the availability of the serviceability assurance subsystem it is necessary to define the types as well as outlining the values of the parameters of distributions of the times of availability and the times of renovation of individual posts of the subsystem. In the analysis of the systems of assuring the serviceability of technological objects, the often used types of distributions of the times of serviceability and times of renovation are the following distributions: exponential and Erlang.

This article determines the availability of serviceability assurance subsystem posts, under the assumption that the times of availability and the times of renovation of individual posts have exponential and Erlang distributions. Using the resulting formulas for exponential distribution is limited only to the case of the analyzed random variables having exponential distributions (the so called "no memory" models) $[1,5,10]$. On the other hand, the resulting characteristics for Erlang distribution, are useful when the analyzed random variables are the sum of independent random variables with exponential distribution. Then, the analyzed random variables may be presented as follows $[2,3,8,14]$ :

$$
X_{i j}=X_{i j}^{1}+X_{i j}^{2}+\ldots+X_{i j}^{m}
$$

where $X_{i j}^{1}, X_{i j}^{2}, \ldots, X_{i j}^{m}$ are independent random variables (the times of serviceability of a single post) with exponential distribution with parameter $\lambda_{i j}$;

$$
Y_{i j}=Y_{i j}^{1}+Y_{i j}^{2}+\ldots+Y_{i j}^{n}
$$

where $Y_{i j}^{1}, Y_{i j}^{2}, \ldots, Y_{i j}^{n}$ are independent random variables (the times of renovation of a single post) with exponential distribution with parameter $\mu_{i j}$.

Below, we present the formulas for defining the availability of the serviceability assurance subsystem posts determined for exponential and Erlang distributions. 
Availability of the serviceability assurance subsystem posts - exponential distribution

If random variables describing the times of serviceability $X_{i j}$ as well as times of renovation $Y_{i j}$ of a single post $s_{i j}$ in the serviceability assurance subsystem, defined by an exponential distribution, then the distribution function of a single serviceability assurance subsystem post $s_{i j}$ is defined by the dependence:

$$
V_{i j}(t)=1-e^{-\lambda_{i j} \cdot t}, \quad t \geq 0,
$$

while the distribution function of the time of renovation of a single post $s_{i j}$, by the dependence:

$$
W_{i j}(t)=1-e^{-\mu_{i j} \cdot t}, \quad t \geq 0,
$$

where:

$\lambda_{i j}-$ intensity of damage of a single post $s_{i j}$ in the serviceability assurance subsystem,

$\mu_{i j}-$ intensity of renovation of a single post $s_{i j}$ in the serviceability assurance subsystem.

Taking into consideration the above, the formulas describing limit availability coefficients (for $t \rightarrow \infty$ ) for a single post $s_{i j}$ in the serviceability assurance subsystem determined for exponential distribution are presented through dependencies:

$$
\begin{gathered}
G_{i j}=\lim _{t \rightarrow \infty} G_{i j}(t)=\frac{\frac{1}{\lambda_{i j}}}{\frac{1}{\lambda_{i j}}+\frac{1}{\mu_{i j}}}=\frac{\mu_{i j}}{\lambda_{i j}+\mu_{i j}}, \\
G_{O i j}(\tau)=\lim _{t \rightarrow \infty} G_{O i j}(t, \tau)=\frac{\mu_{i j}}{\lambda_{i j}+\mu_{i j}} \cdot \lambda_{i j} \cdot \int_{\tau}^{\infty} e^{-\lambda_{i j} \cdot x} d x=\frac{\mu_{i j}}{\lambda_{i j}+\mu_{i j}} \cdot e^{-\lambda_{i j} \cdot \tau} .
\end{gathered}
$$

\section{Availability of the serviceability assurance subsystem posts - Erlanga distribution}

If random variables describing the times of serviceability $X_{i j}$ as well as the times of renovation $Y_{i j}$ of a single post $s_{i j}$ in the serviceability assurance subsystem are defined by Erlang distribution, respectively with parameters $\left(r_{i j}, \theta_{i j}\right)$ and $\left(z_{i j}, v_{i j}\right)$, where:

$r_{i j} \quad-$ parameter of the shape of Erlang distribution for random variable $X_{i j}$ (positive integer), 
The evaluation of availability of the serviceability assurance subsystem posts Ocena gotowości stanowisk podsystemu zapewniania zdatności

$$
\begin{aligned}
& \theta_{i j}=\frac{1}{\lambda_{i j}} \quad-\text { parameter of Erlang distribution scale for random variable } \\
& X_{i j} \text { (positive integer), } \\
& \lambda_{i j} \quad-\text { relative frequency of Erlang distribution for random variable } \\
& X_{i j} \text { (positive real number), } \\
& z_{i j} \quad-\text { parameter of the shape of Erlang distribution for random } \\
& \text { variable } Y_{i j} \text { (positive integer), } \\
& v_{i j}=\frac{1}{\mu_{i j}} \quad-\text { parameter of Erlang distribution scale for random variable } Y_{i j} \\
& \text { (positive real number), } \\
& \mu_{i j} \quad-\text { relative frequency of Erlang distribution for random variable } \\
& Y_{i j} \text { (positive real number). }
\end{aligned}
$$

Taking the above into consideration, the average values of the time of serviceability $X_{i j}$ and the time of renovation $Y_{i j}$ of a single post $s_{i j}$ in the serviceability assurance subsystem are presented through the dependencies:

$$
\begin{aligned}
& E X_{i j}=r_{i j} \cdot \theta_{i j}=\frac{r_{i j}}{\lambda_{i j}}, \\
& E Y_{i j}=z_{i j} \cdot v_{i j}=\frac{z_{i j}}{\mu_{i j}} .
\end{aligned}
$$

Then the formulas describing the limit availability coefficients (for $t \rightarrow \infty$ ) of a single post $s_{i j}$ in the serviceability assurance subsystem, determined for Erlang distribution, are presented through the dependencies:

$$
\begin{gathered}
G_{i j}=\lim _{t \rightarrow \infty} G_{i j}(t)=\frac{\frac{r_{i j}}{\lambda_{i j}}}{\frac{r_{i j}}{\lambda_{i j}}+\frac{z_{i j}}{\mu_{i j}}}=\frac{r_{i j} \cdot \mu_{i j}}{r_{i j} \cdot \mu_{i j}+z_{i j} \cdot \lambda_{i j}}, \\
G_{O i j}(\tau)=\frac{1}{\frac{r_{i j}}{\lambda_{i j}}+\frac{z_{i j}}{\mu_{i j}}} \cdot \int_{\tau}^{\infty} \int_{\lambda_{i j} x}^{\infty} \frac{u^{r_{i j}-1}}{\left(r_{i j}-1\right) !} e^{-u} d u d x .
\end{gathered}
$$

\section{Test results}

Presented below are selected results of the evaluation of availability of serviceability assurance subsystem posts in the tested actual transport means utilization system. Basing on the identification of the analyzed subsystem of 
serviceability assurance, the following qualitatively varied (due to the type and range of carried out tasks) post units were delineated:

- Unit of services on operation day posts Z1, comprised of 2 posts conjugated via series structure.

- Unit of periodic maintenance services Z2 (1 post).

- Unit of running repair posts Z3, comprising of 16 posts conjugated by threshold structure (10 out of 16 posts).

- Unit of specialist repair posts Z4, comprising of 7 posts conjugated by series structure.

Basing on the set of operational data obtained from tests on an actual transport means system, the values of availability were estimated for availability of individual types of serviceability assurance subsystem posts. Availability of the posts of the analyzed serviceability assurance subsystem was defined in two cases:

1) When times of serviceability and renovation of serviceability assurance subsystem posts have exponential distribution,

2) When times of serviceability and renovation of serviceability assurance subsystem posts have Erlang distribution.

Selected characteristics describing availability of serviceability assurance subsystem posts in the tested actual transport means system are presented below (figures 1 to 4 ).

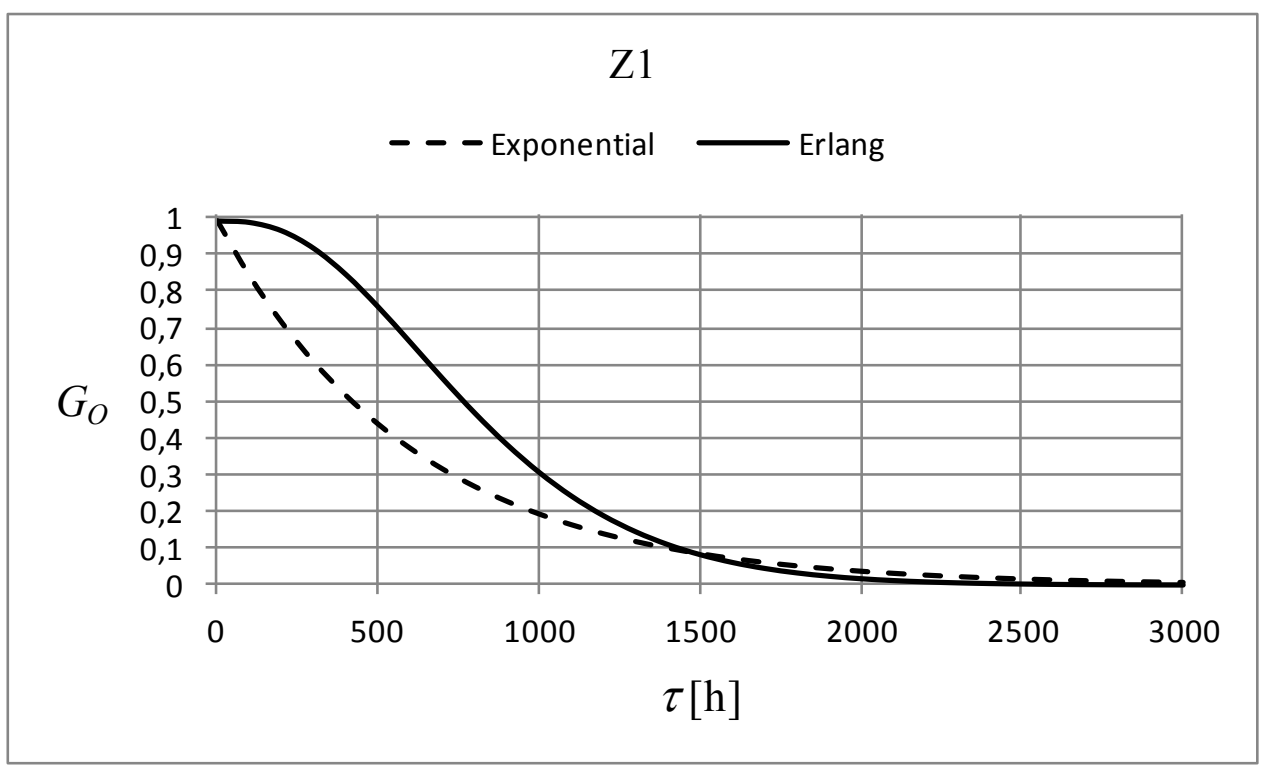

Fig. 1. Availability of service posts on the day of operation in the serviceability assurance subsystem 
The evaluation of availability of the serviceability assurance subsystem posts Ocena gotowości stanowisk podsystemu zapewniania zdatności

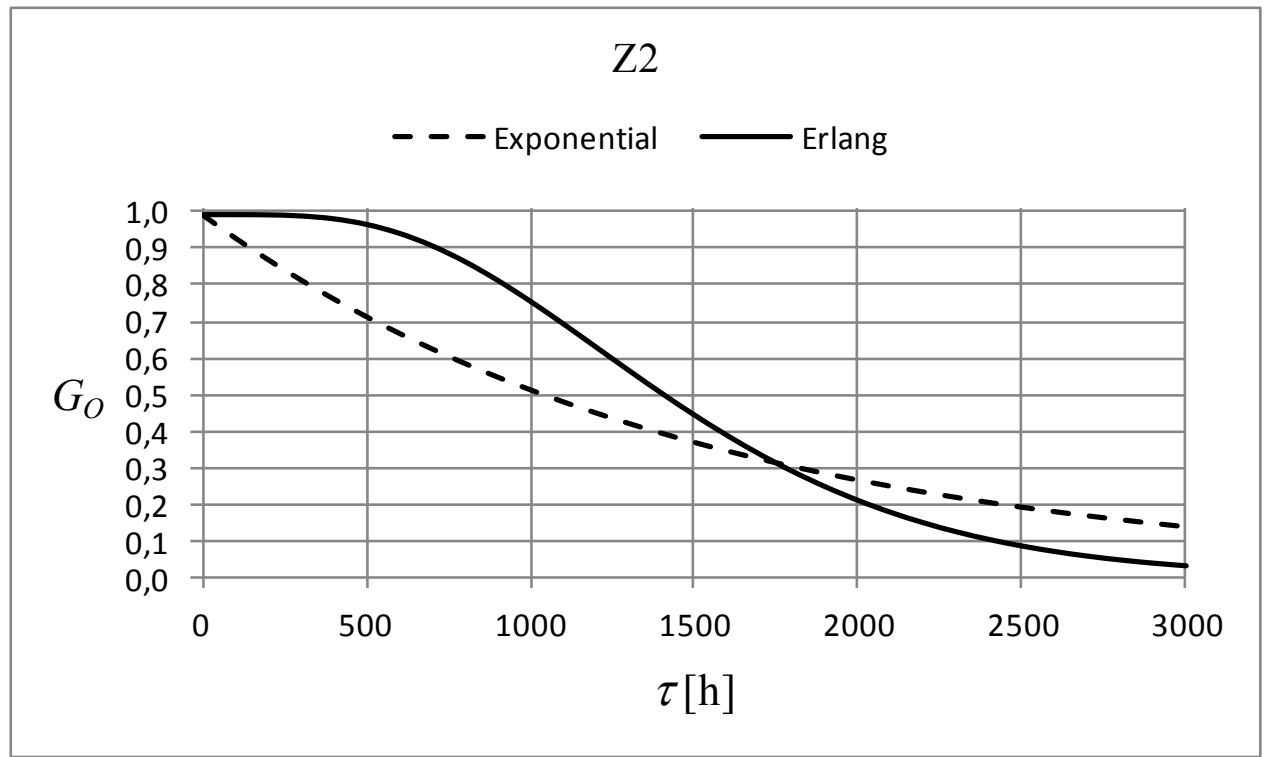

Fig. 2. Availability of periodical maintenance services posts in serviceability assurance subsystem

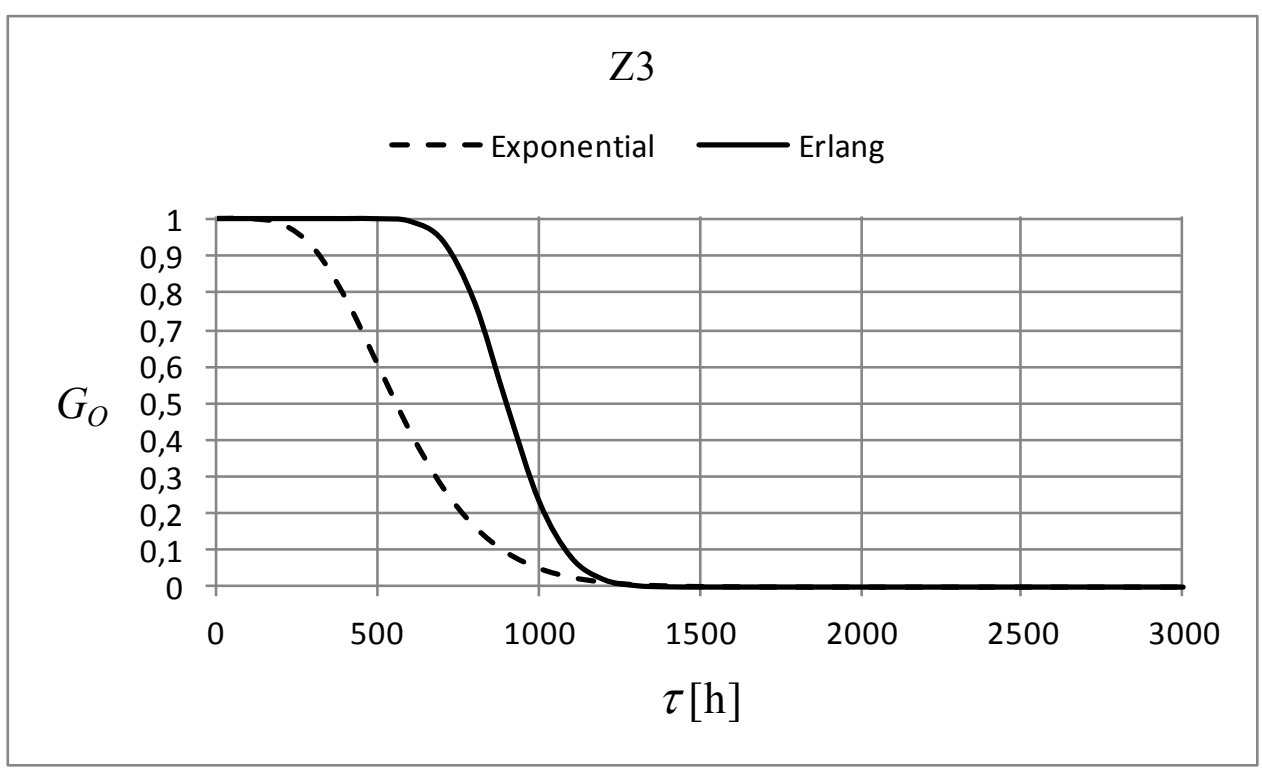

Fig. 3. Availability of running repair posts in serviceability assurance subsystem 


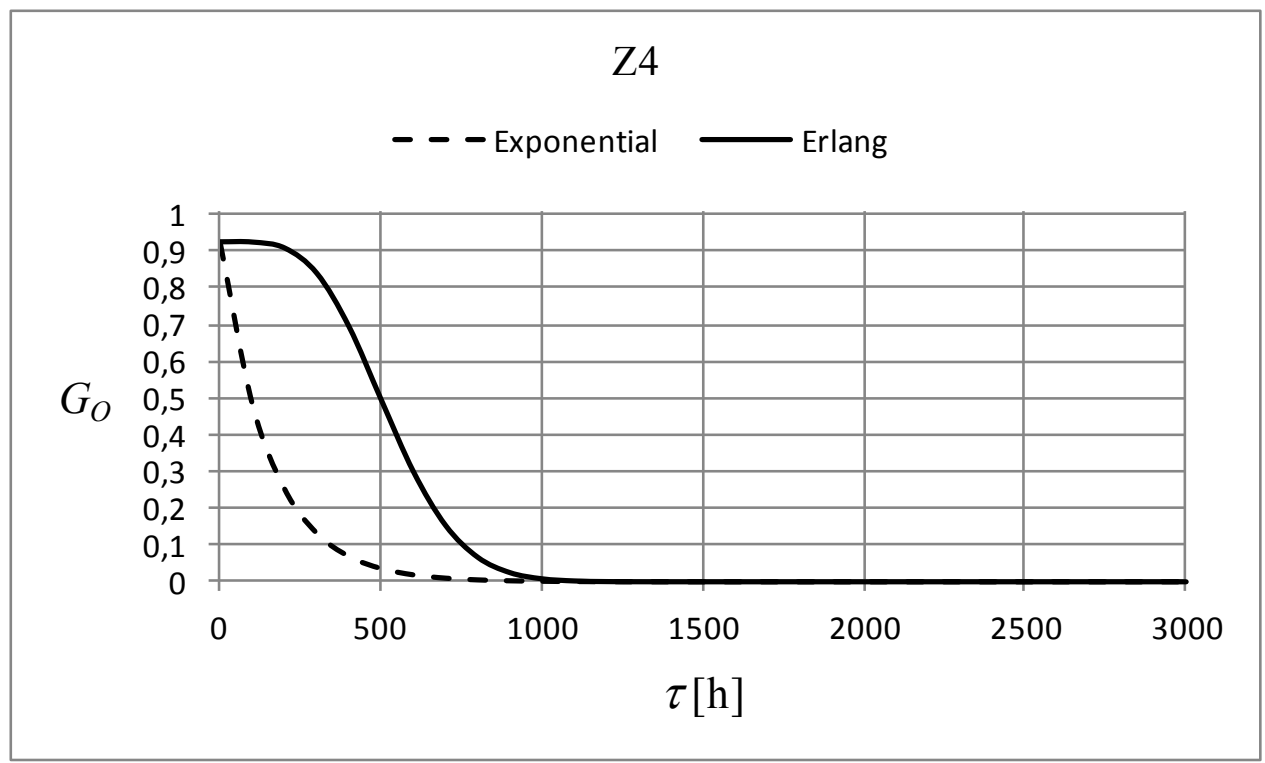

Fig. 4. Availability of specialist repair posts in serviceability assurance subsystem

\section{Summary}

In the analysis of the systems of servicing technological objects, among often used types of time distribution between consecutive reports as well as time of servicing are exponential and Erlang distributions. Assuming the exponential time distribution is, first of all, convenient form mathematical point of view and second of all, results from the fact that using exponential facilitates a precise enough analysis of the operation of any service system, when one analyzes the case of a "no memory" system. Then the probability of completing the servicing of a technological object over any consecutive time interval is independent of the length of the time interval assigned for its service [1, 2, 7, 16, 17]. Using Erlang distribution makes it possible to analyze a wider class of technological objects service systems for which times between consecutive reports and service times may be described with the help of exponential distribution, gamma distribution as well as the analysis of periodical or regular report times when the length of interval between consecutive reports is constant $[2,3,5,10]$.

This article presented the results of the evaluation of the availability of individual types of serviceability subsystem posts. The presented method of delineating and evaluation of the availability of serviceability assurance subsystem posts may be used for single posts, units of posts of a given type, e.g. running repairs posts unit, as well as the subsystem of serviceability assurance as a whole. Due to its general character, the presented method may also be used to define the availability of such subsystems as diagnostic, supply, intervention etc.. The evaluation of the 
The evaluation of availability of the serviceability assurance subsystem posts Ocena gotowości stanowisk podsystemu zapewniania zdatności

availability of serviceability assurance subsystem may constitute the basis for decision-making as to, e.g. change of the number and type of the used service and repair posts in the tested system as well as modification of the carried out operational strategy.

\section{References}

[1] Abezgauz G.G. Troń A.P. Kopenkin J.N. Korowina I.A.: Rachunek probabilistyczny - poradnik, WMON, Warszawa, 1973.

[2] Buslenko N.P. Kałasznikow W.W. Kowalenko I.N.: Teoria systemów złożonych, PWN, Warszawa, 1979.

[3] Cox D.R. Miller H.D.: The theory of stochastic processes, Chapman and Hall, London, 1965.

[4] Gołąbek A.: Metoda określania struktury systemu obsługi pojazdu samochodowego, Zagadnienia Eksploatacji Maszyn, zeszyt nr 3-4 (59-60), 1984.

[5] Houlden P.T.: Z praktyki badań operacyjnych, PWE, Warszawa, 1964.

[6] Jaźwiński J. Grabski F.: Niektóre problemy modelowania systemów transportowych, Instytut Technologii Eksploatacji, Warszawa-Radom, 2003.

[7] Kopociński B.: Zarys teorii odnowy i niezawodności, PWN, Warszawa, 1973.

[8] Kosten L.: Stochastic theory of service systems, Pergamon Press, London, 1973.

[9] Koźniewska J. Włodarczyk M.: Modele odnowy, niezawodności i masowej obsługi, PWN, Warszawa, 1978.

[10] Kukuła K.: Badania operacyjne w przykładach i zadaniach, PWN, Warszawa, 1998.

[11] Okulewicz J. Smalko Z.: Wyznaczanie technicznie uzasadnionej liczby stanowisk obsługowo-naprawczych, Instytut Transportu Politechniki Warszawskiej, zeszyt $28,1988$.

[12] Oziemski S.: Efektywność eksploatacji maszyn, Podstawy technicznoekonomiczne, Instytut Technologii Eksploatacji, Radom, 1999.

[13] Piasecki S.: Zagadnienia organizacji obsługi technicznej maszyn i środków transportowych, Lubelskie Towarzystwo Naukowe, Warszawa-Lublin, 1996.

[14] Schassberger R.: Warteschlangen, Springer-Verlag, Berlin, 1973.

[15] Taha H. A.: Operations research, Macmillan Publishing Co., New York, 1982.

[16] Wagner H.M.: Badania operacyjne, PWE, Warszawa, 1980.

[17] Woropay M. Żurek J. Migawa K.: Model oceny i kształtowania gotowości operacyjnej podsystemu utrzymania ruchu w systemie transportowym, Instytut Technologii Eksploatacji, Radom, 2003.

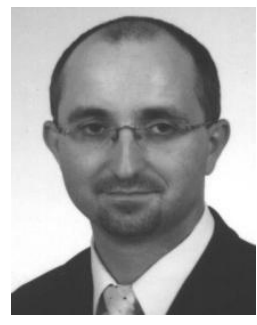

Ph.D Klaudiusz Migawa works in Transport Department at the Mechanical Engineering Faculty of the University of Technology and Life Sciences in Bydgoszcz. In his scientific research he focuses on the problems of modeling and control of processes carried out in complex technological object operation systems. He conducts research on the evaluation of availability and reliability in operation systems of municipal bus transport. 